\title{
Potensi Pati Sagu Dan Pendapatan Masyarakat Di Kampung Mega Distrik Mega Kabupaten Sorong
}

\author{
Lona Helti Nanlohy'; Muzna A.A. Gafur ${ }^{2}$ \\ Universitas Muhammadiayh Sorong \\ ${ }^{1}$ lonaheltinanlohy@gmail.com
}

\begin{abstract}
Abstrak
Sagu adalah tumbuhan penghasil karbihodrat, sagu dapat dimanfaatkan dalam bentuk pati yang dapat diproses menjadi produk-produk makanan dan lainnya. Masyarakat Papua selama ini memanfaatkan Pati sagu sebagai makanan pengganti karbohidrat seperti beras, ubi kayu ataupun ubi jalar. Pati sagu diproses menjadi makanan tradisional berupa papeda, sagu lempeng dan sagu bungkus. Penelitian ini bertujuan untuk mengetahui potensi pati sagu dan pendapatan masyarakat di Kampung Mega Distrik Mega Kabupaten Sorong. Pengukuran Potensi sagu dilakukan melalui metode survey dengan pangamatan dan pengukuran langsung di lapangan Pengukuran Potensi pati sagu dilakukan dengan pengukuran diameter pohon sagu $(\mathrm{cm})$ dan tinggi pohon sagu (m) pengukuran potensi pati sagu di batasi pada tumbuhan sagu fase Masak tebang (MT). Metode yang digunakan untuk pengukuran kerapatan pohon sagu masak tebang adalah metode jalur. Metode pengambilan contoh untuk responden dipilih dengan teknik Purposive Sampling melalui pemilihan yang disengaja dengan tujuan untuk mendapat data perhitungan pendapatan masyarakat yang memanfaatkan dan mengolah sagu. Potensi pati sagu rata-rata perpohon adalah $282,36 \mathrm{~kg}$ dengan diameter pohon sagu berkisar antara 37 sampai $57 \mathrm{~cm}$ dengan rata-rata $47 \mathrm{~cm}$, sedangkan tinggi pohon berkisar antara 15 sanpai $25 \mathrm{~m}$ dengan rata-rata 19,26 m. Luas areal yang menjadi sampel penelitian adalah $5 \mathrm{Ha}$ dari 100 ha luas keseluruhan hutan sagu. Ditemukan 74 pohon sagu masak tebang (MT) sehingga hasil perhitungan potensi pohon sagu masak tebang (MT) adalah 14.8 pohon/Ha. Pendapatan masyarakat adalah sebesar Rp. 31.410.000/bulan atau rata-rata Rp. 1.847.647/bulan.
\end{abstract}

Kata Kunci: Potensi, Pendapatan, Masyarakat, Pati sagu

\section{PENDAHULUAN}

Tumbuhan sagu adalah salah satu hasil hutan yang dapat dimanfaatkan. Sagu merupakan salah satu penghasil karbohidrat, sagu dapat dimanfaatkan dalam bentuk pati yang dimanfaatkan dan diproses menjadi berbagai produk. Masyarakat Papua selama ini memanfaatkan Pati sagu sebagai makanan pengganti karbohidrat seperti beras, ubi kayu ataupun ubi jalar. Pati sagu diproses menjadi makanan tradisional berupa papeda, sagu lempeng dan sagu bungkus.

Tumbuhan sagu biasanya tumbuh di daerah berrawa atau ekosistem air tawar. Di Papua Sagu yang ditemukan terdiri dari berbagai jenis, dan telah diketahui jenisnya sebanyak 60 jenis (Widjono, dkk, 2000). Sekitar 40\% dari sagu yang tumbuh di Papua (seluas 300.000 ha) merupakan tumbuhan yang termasuk dalam tumbuhan masak 


\section{Median Volume 12 Nomor 1 Bulan Februari 2020}

Doi http://doi.org/md.v12i1.211

tebang (MT). Sagu termasuk jenis tanaman tahunan dimana tanaman sagu tersebut dapat diambil hasilnya selama bertahun-tahun (Badan Pusat Statistik Propinsi Papua, 2007).

Sagu merupakan tanaman penghasil pati, dalam satu batang sagu diperkirakan mengandung pati 200-400 kg. Sedangkan produksi pati kering di Propinsi Maluku dapat mencapai $345 \mathrm{~kg} /$ pohon (Bintoro, dkk 2013). Diasumsikan bahwa pada satu pohon sagu yang mengandung $300 \mathrm{~kg}$ pati maka dalam satu hektar dapat dipanen 30 ton pati. Selain sagu tanaman yang menghasilkan karbohidrat lainnya antara lain padi menghasilkan 5-6 ton, jagung 3-4 ton, dan ubi kayu 10 ton (Wiyono dan Silitonga, 1989) diacu dalam. Rachmawati (2013)

Potensi sagu apabila dikelola oleh masyarakat dengan memperhatikan prosedur yang baik dan benar menghasilkan pati sagu yang berkualitas dan jumlah pati yang banyak sehingga mencukupi kebutuhan karbohodrat yang dibutuhkan. Pati sagu sebagaimana pati dari tanaman padi, jagung maupun ubi kayu dapat diolah dan diproses menjadi berbagai macam kebutuhan yang dapat dimanfaatkan oelh masyarakat, misalnya sebagai makanan pokok maupun dapat diolah untuk berbagai kebutuhan berbahan dasar pati sagu.

Kampung Mega merupakan salah satu kampung yang memiliki potensi sagu yang dapat dikembangkan dan dimanfaatkan. Berdasarkan hal tersebut maka perlu dilakukan penelitian menyangkut potensi pati sagu dan pendapatan masyarakat dikampung Mega Distrik Mega Kabupaten Sorong, sehingga dapat diperoleh data dan informasi yang akurat sehingga potensi pati sagu sebagai bahan baku berberbagai produk dapat dikelola dengan baik untuk dapat dimanfaatkan secara baik dan benar untuk menambah pendapatan memenuhi kebutuhan masyarakat.

Tujuan dari penelitian ini adalah untuk mengetahui potensi pati sagu dan pendapatan masyarakat di Kampung Mega Distrik Mega Kabupaten Sorong.

\section{METODOLOGI PENELITIAN}

Pengukuran Potensi sagu dilakukan melalui metode survey dengan pangamatan dan pengukuran langsung di lapangan. Pengukuran langsung dilapangan yaitu pengukuran diameter pohon sagu $(\mathrm{cm})$ dan tinggi pohon sagu $(\mathrm{m})$ pengukuran potensi sagu di batasi hanya pada tumbuhan sagu fase Masak tebang (MT). Luas keseluruhan hutan sagu di kampung Mega Distrik Mega Kabupaten Sorong adalah seluas 100 Ha. Metode yang digunakan untuk pengukuran kerapatan pohon sagu masak tebang adalah metode jalur. Intensitas sampling untuk penelitian ini adalah $5 \%$.. Luas areal yang menjadi sampel penelitian adalah $5 \mathrm{Ha}$ dengan panjang jalur $500 \mathrm{~m}$ dan lebar 20 m.dan dibuat 5 jalur pengamatan. Metode pengambilan contoh untuk responden dipilih dengan teknik Purposive Sampling melalui pemilihan yang disengaja dengan tujuan untuk mendapatkan data perhitungan pendapatan masyarakat yang memanfaatkan dan mengolah sagu. Jumlah responden sebanyak $17 \mathrm{KK}$. Responden adalah petani sagu atau masyarakat pemanfaat dan pengolahan sagu. Data hasil penelitian selanjutnya dianalisis yaitu: 


\section{Median Volume 12 Nomor 1 Bulan Februari 2020}

Doi http://doi.org/md.v12i1.211

Potensi Sagu : Perhitungan analisa potensi sagu di batasi pada fase Masak tebang (MT), karena diasumsikan bahwa fase masak tebang tumbuhan sagu merupakan fase dimana tumbuhan sagu sudah siap dipanen atau ditebang untuk diambil patinya.

Rumus yang dipakai untuk menghitung potensi sagu yaitu :

Potensi Sagu $=\underline{\text { Jumlah jenis sagu Masak tebang }}$

Luas areal penelitian

Potensi Pati Sagu: Untuk menduga potensi pati sagu per pohon menggunakan persamaan yang dikembangkan oleh Yumte (2008, yaitu:

$W s=1,792\left(D_{b h}\right)^{0,648}\left(T_{b p}\right)^{0,874}$

Dimana :

$W_{s}=$ Kandungan pati sagu $(\mathrm{kg} /$ pohon $)$

$D_{b h}=$ Diameter setinggi dada $(\mathrm{cm})$

$T_{b p}=$ Tinggi Bebas pelepah (m)

Pendapatan Masyarakat: Perhitungan pendapatan masyarakat berdasarkan harga pasar (Market Price) dengan rumus (Suratyah, 2006) sebagai berikut:

$\mathrm{I}=\mathrm{TR}-\mathrm{TC}$

Dimana :

I = Pendapatan bersih/bln

$\mathrm{TR}=$ Total pendapatan/bln

$\mathrm{TC}=$ Total biaya/bln

$\mathrm{TR}=\sum \mathrm{Qi} . \mathrm{Pi}$

Dimana :

TR $=$ Total Pendapatan/bln

$\mathrm{Qi}=$ Jumlah produksi/bln

$\mathrm{Pi}=$ Harga produksi

\section{HASIL DAN PEMBAHASAN}

\section{Potensi Sagu (Pohon/Ha)}

Hasil penelitian menunjukan bahwa terdapat tiga jenis sagu di Kampung Mega Distrik Mega Kabupaten Sorong berdasarkan morfologi pohon sagu (Limbongan, 2007) yaitu sagu Tuni (Metroxylon rumphii Martius), sagu Molat (Metroxylon sagus Rottb). dan Sagu Rotan (Metroxylon micracamthum Mart), Hasil pengukuran pohon sagu masak tebang (MT) terdapat 74 pohon, sehingga hasil perhitungan potensi pohon sagu masak tebang (MT) adalah 14.8 pohon/Ha.

\section{Potensi Pati Sagu}

Besarnya potensi pati sagu di Kampung Mega Distrik Mega Kabupaten Sorong diperoleh dengan menggunakan perhitungan kandungan pati sagu yang dapat dilihat pada tabel 1 . 
Doi http://doi.org/md.v12i1.211

Tabel 1. Potensi Pati Sagu Perpohon di Kampung Mega Distrik Mega Kabupaten Sorong

\begin{tabular}{clccc}
\hline No & Jenis Sagu & $\begin{array}{c}\text { Diamater } \\
(\mathrm{cm})\end{array}$ & $\begin{array}{c}\text { Tinggi } \\
(\mathrm{m})\end{array}$ & $\begin{array}{c}\text { Potensi Pati Sagu } \\
(\mathrm{Kg} / \mathrm{pohon})\end{array}$ \\
\hline 1 & Sagu Tuni & $38-58$ & $15-25$ & $223.85-396.03$ \\
2 & Sagu Molat & $41-61$ & $15-23$ & $230.01-335.42$ \\
3 & Sagu Rotan & $38-57$ & $17-24$ & $236.27-319.17$ \\
\hline
\end{tabular}

Sumber : Data Hasil Olahan Penelitian 2019

Berdasarkan hasil penelitian pada tabel 2 menunjukan bahwa diameter pohon sagu berkisar antara 38 sampai $61 \mathrm{~cm}$ dengan rata-rata $47 \mathrm{~cm}$, sedangkan tinggi pohon berkisar antara 15 sampai $25 \mathrm{~m}$ dengan rata-rata 19,26 $\mathrm{m}$. Potensi pati sagu rata-rata perpohon adalah 282,36 kg. Beberapa hasil penelitian menunjukan angka yang berbeda untuk potensi pati sagu yaitu penelitian yang dilakukan oleh Haryanto dkk (2015), di Kabupaten Sorong Selatan menunjukan potensi pati sagu rata-rata perpohon adalah $147,8 \mathrm{~kg}$. Tetapi bila dibandingkan dengan penelitian yang dilakukan oleh Louhenapessy, dkk (2011) di Maluku, potensi pati sagu mencapai $640 \mathrm{~kg}$ (berat basah) perpohon. Menurut penelitian Novarianto (2011) menyebutkan pada perkebunan sagu di Kabupaten Meranti Propinsi Riau, potensi sagu rata-rata $350 \mathrm{~kg}$ perpohon.

Berdasarkan hasil-hasil penelitian terhadap potensi pati sagu perpohon di beberapa lokasi bila dbandingkan dengan potensi pati sagu di Kampung Mega menunjukan bahwa potensi pati sagu perpohon menunjukan bahwa potensi pati sagu melebihi bila dibandingkan dengan penelitian yang dilakukan di Sorong Selatan tetapi lebih rendah dengan potensi pati sagu di Maluku dan Riau, dengan demikian potensi pati sagu di Kampung Mega mempunyai prospek yang baik untuk dikembangkan dengan melakukan berbagai syarat yang harus dipenuhi menyangkut pemeliharaan yang baik melalui pengaturan drainase dan penjarangan, karena semakin besar diameter dan tinggi pohon makan akan semakin besar pula potensi pati sagu yang dihasilkan. Perbedaan produksi pati sagu dari satu daerah dengan daerah lain dapat disebabkan oleh perbedaan varietas sagu, perbedaan lingkungan tumbuh, kesuburan tanah, iklim dll. Hal ini sesuai dengan pendapat dari Bintaro, dkk (2013) yang menyatakan bahwa perbedaan produksi tepung sagu diduga diakibatkan oleh perbedaan tempat tumbuh dan lingkungan yang berbeda.

\section{Pendapatan Masyarakat}

Berdasarkan hasil wawancara yang dilakukan terhadap masyarakat pemanfaat sagu, dketahui bahwa sagu memberikan hasil yang baik bagi masyarakat, terutama masyarakat pengolah sagu. Hasil wawancara dengan masyarkat/responden menunjukan bahwa untuk satu pohon sagu saja responden memperoleh produksi pati (tumang) sebanyak 5-6 tumang, hasil yang diperoleh sesuai dengan besarnya pohon sagu. Panjang pohon dan diameter batang pohon sagu dan juga tergantung pada teknik meremas sagu tersebut, apabila dilakukan peremasan dengan baik dan teliti maka akan menghasilkan pati sagu dalam jumlah yang banyak, sebaliknya apabila dilakukan peremasan pati sagu 


\section{Median Volume 12 Nomor 1 Bulan Februari 2020}

Doi http://doi.org/md.v12i1.211

dengan kondisi kelelahan dan kurang teliti, maka pati sagu yang dihasilkan juga akan sedikit. Frekwensi pengolahan sagu dari masing-masing responden juga berbeda-beda tergantung dari kemampuan masing-masing responden itu sendiri, ada responden yang frekwensi pengolahan sagu mencapai 4 pohon/bulan ada juga yang hanya 1 pohon/bulan, frekwensi pengolahan sagu peresponden dapat dilihat pada gambar 1 .

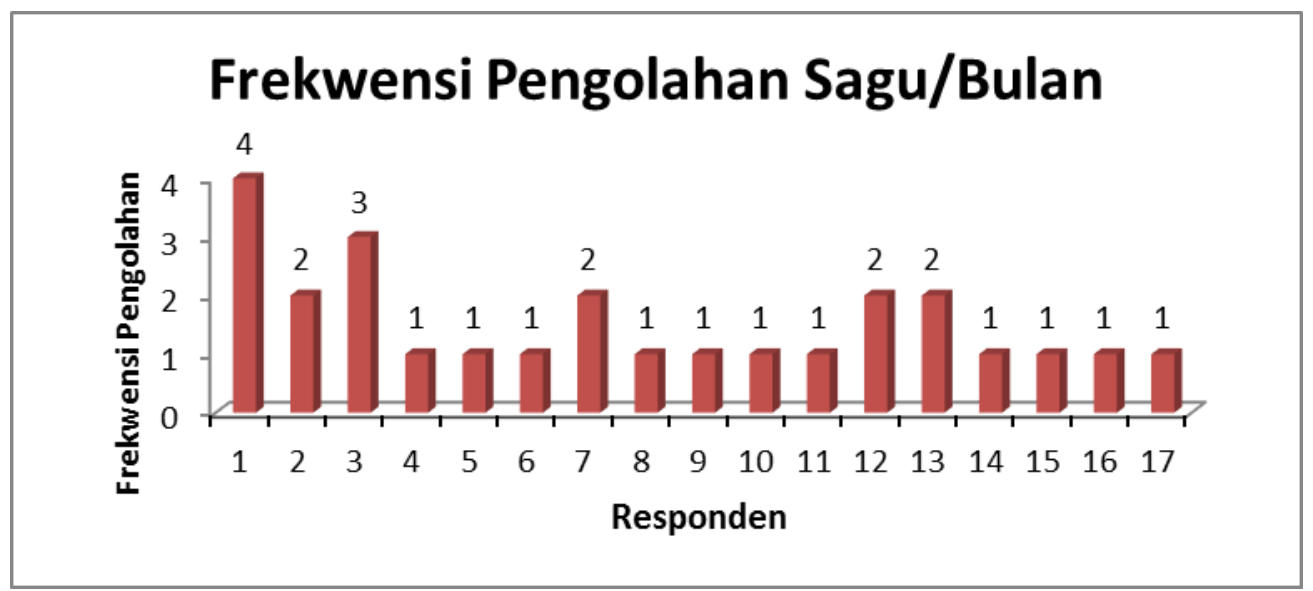

Gambar 1. Frekwensi Pengolahan Sagu/Bulan

Berdasarkan perhitungan pendapatan masyarakat berdasarkan harga pasar (Market Price) dari produksi pati sagu dapat dilihat pada tabel 2.

Tabel 2. Hasil Pendapatan Masyarakat dari Produksi Pati Sagu

\begin{tabular}{ccccc}
\hline Responden & $\begin{array}{c}\text { Hasil } \\
\text { produksi } \\
\text { tumang/bln })\end{array}$ & $\begin{array}{c}\text { Total } \\
\text { Pendapatan } \\
\text { (Rp/bln) }\end{array}$ & $\begin{array}{c}\text { Biaya Total } \\
\text { Pengeluaran } \\
\text { (Rp/bulan) }\end{array}$ & $\begin{array}{c}\text { Pendapatan } \\
\text { Bersih /Bln }\end{array}$ \\
\hline 1 & 20 & 6000000 & 860.000 & 5140000 \\
2 & 12 & 3600000 & 690.000 & 2910000 \\
3 & 16 & 4800000 & 680.000 & 4120000 \\
4 & 6 & 1800000 & 620.000 & 1180000 \\
5 & 6 & 1800000 & 600.000 & 1200000 \\
6 & 6 & 1800000 & 600.000 & 1200000 \\
7 & 10 & 3000000 & 680.000 & 2320000 \\
8 & 5 & 1500000 & 620.000 & 880000 \\
9 & 5 & 1500000 & 620.000 & 880000 \\
10 & 6 & 1800000 & 620.000 & 1180000 \\
11 & 6 & 1800000 & 620.000 & 1180000 \\
12 & 12 & 3600000 & 720.000 & 2880000 \\
13 & 10 & 3000000 & 720.000 & 2280000 \\
14 & 5 & 1500000 & 620.000 & 880000 \\
15 & 5 & 1500000 & 600.000 & 900000 \\
16 & 6 & 1800000 & 620.000 & 1180000 \\
17 & 6 & 1800000 & 700.000 & 1100000 \\
\hline Jumlah & & 42.600 .000 & 11.190 .000 & 11.190 .000 \\
\hline Rat-rata & & 2.505 .882 & 658.235 & 1.847 .647 \\
\hline
\end{tabular}

Sumber: Data Hasil Olahan Penelitian 2019 
Tabel di atas menunjukan bahwa hasil produksi (tumang) masing-masing responden berbeda, ada responden yang dapat memproduksi 20 tumang perbulan, tetapi sebagian besar responden memproduksi 5-6 tumang/bln. Hal ini disesuaikan dengan frekwensi pengolahan sagu yang dilakukan. Harga jual pertumang untuk semua responden yaitu sebesar Rp. 300.000/tumang. Sehingga dari hasil perhitungan diperoleh total pendapatan bersih seluruh responden yaitu Rp. 31.410.000/bulan. Sedangkan pendapatan bersih rata-rata tiap responden adalah Rp. 1.847.647/bulan. Pendapatan bersih responden antara Rp. 880.000/bulan sampai Rp. 5.140.000/bulan. Total pengeluaran selama pengambilan sagu antara Rp. 600.000 sampai Rp. 860.000/bulan. Pendapatan bersih tiap responden berbeda-beda, hal ini dipengaruhi oleh banyaknya jumlah produksi pati sagu/tumang yang dihasilkan dan besar kecilnya jumlah biaya pengeluaran (Rp/bulan) dimana semakin banyak produksii pati sagu maka semakin besar pendapatan yang diperoleh.

Hasil wawancara dengan masyarakat menunjukan bahwa untuk pemasaran hasil produksi pati sagu dalam bentuk tumang selama ini berjalan lancar, artinya ada pembeli yang langsung membeli ketempat usaha. Hal ini berarti bahwa rantai pemasaran produksi pati sagu berjalan dengan baik.

\section{KESIMPULAN}

Potensi pati sagu rata-rata perpohon adalah $282,36 \mathrm{~kg}$ dengan diameter pohon sagu berkisar antara 38 sampai $61 \mathrm{~cm}$ dengan rata-rata $47 \mathrm{~cm}$, sedangkan tinggi pohon berkisar antara 15 sanpai $25 \mathrm{~m}$ dengan rata-rata 19,26 $\mathrm{m}$. Luas areal yang menjadi sampel penelitian adalah 5 Ha dari 100 ha luas keseluruhan hutan sagu. Ditemukan 74 pohon sagu masak tebang (MT) sehingga hasil perhitungan potensi pohon sagu masak tebang (MT) adalah 14.8 pohon/Ha. Pendapatan masyarakat adalah Rp. 31.410.000/bulan atau rata-rata Rp. 1.847.647/bulan.

\section{DAFTAR PUSTAKA}

Badan Pusat Statistik Propinsi Papua, 2007. Papua dalam Angka Tahun 2004/2005. Badan Pusat Statistik Provinsi Papua. Jayapura.

Bintaro, D. Shandra A, Ratih K.D, Destieka A. 2013. Sagu Mutiara Hijau Khatulistiwa yang Dilupakan. Digreat Publishing. Bogor.

Hariyanto B, Atmadji P, Putranto A T, Kurniasari I, 2013. Sistem Produksi, Pengolahan dan Pemanfaatan Hutan Sagu Untuk Penyediaan Pangan Karbohidrat di Papua Barat.

Haryanto B. Mubekti dan Putranto A.T, 2015. Potensi dan Pemanfaatan Pati Sagu dalam Mendukung Ketahanan Pangan Di Kabupaten Sorong Selatan Papua Barat. Jurnal Pangan. Vol.24. No.2.

Limbongan, J. 2007. Morfologi Beberapa Jenis Sagu Potensial Di Papua. Jurnal Litbang Pertanian. Jayapura.

Louhenapessy, J.E, A. Sarhana, M. Luhukay, H. Talahattu, F. Polnaya, H. Salampessy, R.B. Riry, A. Ngingi, S. Handal, Ilyas Nurdin, J. Latuputty,. Hursepuny dan 


\section{Median Volume 12 Nomor 1 Bulan Februari 2020}

Doi http://doi.org/md.v12i1.211

Patimukay, 2011. Usulan Pelepasan Varietas Sagu Molat Maluku. Dinas

Pertanian Propinsi Maluku dan BBP2TO Ambon. Dirjen PerkebunanKementerian Pertanian.

Novarianto, 2011. Sumber Daya Genetik Sagu Mendukung Pengembangan Sagu di Indonesia. Penguatan Inovasi Teknologi Mendukung Kemandirian Usaha Tani Perkebunan Rakyat. Balai Penelitian Tanaman Palma Manado.

Rachmawati, A. 2013. Potensi Sagu Dalam Upaya Diversifikasi Pangan. Universitas Brawijaya Malang.

Suratiyah, K. 2006. Ilmu Usahatani. Penebar Swadaya. Jakarta

Yumte Y, 2008. Penyusunan Model Penduga Berat Basah Tepung Sagu Duri (Metroxylon rumpii) di Kabupaten Sorong Selatan. Thesis S2 Fakultas Kehutanan IPB. Bogor. 